\title{
Genetic epidemiology of mutated K-ras \\ proto-oncogene, altered suppressor genes, and microsatellite instability in colorectal adenomas
}

\author{
A Rashid, M Zahurak, S N Goodman, S R Hamilton
}

\begin{abstract}
Background-The genetic epidemiology of colorectal adenomas has not been studied prospectively in colonoscopy patients without cancer.

Aims-To study genetic alterations in colorectal adenomas and correlate these with patient demographics and adenoma characteristics.

Methods-Mutations and allelic deletions in 201 adenomas from 60 patients were compared with demographic features, adenoma characteristics, and family history.

Results-The most common alteration was K-ras proto-oncogene mutation, present in $35 \%$ of adenomas and $65 \%$ of patients. Patients 65 years of age and older had a decreased probability of K-ras mutations ( $26 \%$ versus $45 \%$ ). Overexpression of p53 gene product was present in only $6 \%$ of adenomas but was more frequent in villous or tubulovillous adenomas $(19 \%$ versus $3 \%)$. Allelic loss of chromosome $18 q$ was present in only $2 \%$ of adenomas and was significantly less frequent than p53 overexpression. DNA replication errors (RER) were present in 7\% of adenomas and $15 \%$ of patients, including multiple adenomas in four patients (two with hereditary non-polyposis colorectal cancer syndrome). Only $36 \%$ of RER positive adenomas had alteration of BAT-26 alleles, none had alteration of BAT-25, and only one $(8 \%)$ had mutation in the transforming growth factor $\beta$ type II receptor gene. RER positive adenomas were more likely to have a K-ras mutation. In patients with multiple adenomas, there was concordance of p53 overexpression and RER but not of K-ras mutations.

Conclusions-Genetic progression in colorectal adenomas is heterogeneous, involving factors related to patient age and the presence of RER for the occurrence of ras mutations, but different intraindividual characteristics for the occurrence of p53 alterations and RER. (Gut 1999;44:826-833)
\end{abstract}

Keywords: K-ras mutation; p53 gene; loss of 18q; microsatellite instability; replication error; TGF $\beta$ RII

Colorectal cancer is the second most common cause of cancer deaths in the USA. Most colorectal cancers develop from adenomatous polyps, and morphological and genetic pro- gression in an adenoma-adenocarcinoma sequence and in hereditary colorectal cancer is well described. ${ }^{1-4}$

The molecular genetic alterations in sporadic and hereditary colorectal neoplasms are well understood and involve two distinct pathways. ${ }^{1-4}$ The genetic alterations present in most colorectal cancers are also present in adenomas and include truncating mutation or deletion of the adenomatous polyposis coli (APC) gene on chromosome $5 \mathrm{q}^{5-7}$ point mutation of K-ras proto-oncogene, ${ }^{8-16}$ loss of the deleted in colorectal cancer (DCC) gene and nearby genes on chromosome $18 \mathrm{q},{ }^{7}{ }^{17-19}$ and mutation and/or deletion of the $\mathrm{p} 53$ gene on chromosome 17p..$^{8}{ }^{20-23}$ Germline mutation of APC causes familial adenomatous polyposis (FAP). ${ }^{5}$ Alteration of the APC gene and K-ras mutations are genetic events observed early in the adenoma-carcinoma sequence, ${ }^{5}$ while loss of chromosome 18q and alteration of p53 are late events. A K-ras independent pathway of colonic carcinogenesis pathway may also exist in right sided colon carcinomas, which can develop from flat adenomas. ${ }^{11} 2425$

In the second pathway to colorectal neoplasia, DNA replication errors (RER; microsatellite instability, ubiquitous somatic mutations) are caused by mutations in nucleotide mismatch repair genes, including hMSH2, hMLH1, PMS1, PMS2, and GTBP. ${ }^{1-4}$ Germline mutation of one of the mismatch repair genes causes hereditary non-polyposis colorectal cancer syndrome (HNPCC). RER is characterised by additions and deletions of nucleotides in numerous repeated nucleotide sequences (microsatellites). RER positive colorectal carcinomas are more commonly right sided and poorly differentiated with a diploid cell population; patients with these cancers have better survival. Alteration of a 10 basepair (bp) polyadenine tract in the transforming growth factor $\beta$ type II receptor (TGF $\beta$ RII) gene is present in more than $90 \%$ of RER positive carcinomas. ${ }^{26}{ }^{27}$ RER and alterations of TGF $\beta$ RII are also reported in colorectal adenomas. ${ }^{27-33}$

Although these genetic events have been studied extensively in sporadic colorectal

Abbreviations used in this paper: APC, adenomatous polyposis coli; DCC, deleted in colorectal cancer; FAP, familial adenomatous polyposis; HNPCC, hereditary non-polyposis colorectal cancer; LOH, loss of heterozygosity; PCR, polymerase chain reaction; RER, replication error; TGF $\beta$ RII, transforming growth factor $\beta$ type II receptor. 
carcinomas, in adenomas with a contiguous or synchronous carcinoma, and in patients with familial colorectal tumours and precursors (FAP and HNPCC), ${ }^{1-35631}$ these events have not been investigated in a prospective study of sporadic colorectal adenomas removed at colonoscopy from patients without cancer. We therefore evaluated K-ras point mutations, loss of chromosome 18q, overexpression of p53 gene product, RER phenotype, and mutations of the TGF $\beta$ RII gene in 201 sporadic colorectal adenomas from such a cohort and compared the results with demographics and adenoma characteristics.

\section{Materials and methods}

PATIENT POPULATION

This study included endoscopic biopsy specimens $(n=154)$, polypectomy specimens $(n=44)$, and resection specimens $(n=3)$ of 201 colorectal adenomas which were collected from 60 patients prospectively enrolled at the endoscopy unit of The Johns Hopkins Hospital. Thirty one patients $(52 \%)$ had specimens from two or more colonoscopies. The Joint Committee of Clinical Investigations (institutional review board) of The Johns Hopkins University School of Medicine reviewed and approved the consent forms and procedures used in this study, and written informed consent was obtained from each patient.

ELIGIBILITY CRITERIA AND EXCLUSION CRITERIA Eligibility criteria for recruitment of colonoscopy patients were: (1) history of colorectal adenoma, symptoms and/or signs of colorectal neoplasia, positive faecal occult blood test, or family history of colorectal neoplasia; (2) age 18 years or over; and (3) ability to understand the study. The patients filled out a detailed questionnaire which included presenting complaints, past medical history, and family history.

The exclusion criteria were: refusal to participate, absence of colorectal adenoma at colonoscopy, inability to give informed consent or complete the questionnaire due to lack of English language skills or unsatisfactory mental status, adenomatous polyposis syndrome, presence of or history of colorectal carcinoma, and unsatisfactory genetic analysis of adenoma specimens (no amplification of DNA by polymerase chain reaction assay).

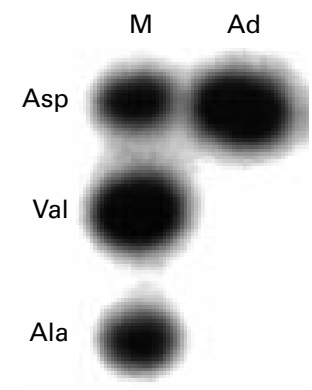

Figure 1 Aspartic acid mutation of codon 12 of $K$-ras gene by ligation of allelic specific

oligonucleotide. M, size marker; Ad, adenoma sample.

Each patient's family history of colorectal cancer was assessed. The patients with a positive family history were characterised as fulfilling criteria for hereditary non-polyposis colorectal cancer (HNPCC) as defined by the International Collaborative Group $^{34}$ when at least three relatives in two successive generations had histologically verified colorectal cancer; at least two were first degree relatives of the third; one member was diagnosed before 50 years of age; and FAP was excluded. The other categories of classification were hereditary colon cancer (at least two successive generations with colorectal cancer, or at least one generation with colorectal cancer and one contiguous generation with adenomatous polyps), family at risk for hereditary colon cancer (two family members with adenomatous polyps or colon cancer in the same generation, or two family members with adenomatous polyps in different successive generations), cancer family syndrome (at least two successive generations with cancer, and at least $50 \%$ of the cancers not colorectal), family at risk for cancer family syndrome (multiple non-colorectal cancers in one generation), and young colon cancer (colon cancer under age 50 years, applied alone or in combination with the above categories).

SPECIMENS AND ADENOMA CHARACTERISTICS

The haematoxylin and eosin stained slides and paraffin wax embedded, formalin fixed, or Bouin's fixed (prior to 1991) tissue blocks of adenomas were obtained from the surgical pathology files of The Johns Hopkins Hospital. A blood specimen was collected from each patient by venepuncture, processed, and frozen. Polyp size was taken from endoscopy notes $(n=156)$ or alternatively from the pathology specimen $(n=45)$. The site of polyps was taken from the surgical pathology requisition sheet completed by the colonoscopist. The histopathological slides were reviewed by a gastrointestinal pathologist (AR). The villous component of adenomas was estimated from the histopathological sections. The adenomas were classified as tubular if a villous component was present on less than $25 \%$ of the surface, tubulovillous if the villous component was $25-75 \%$, and villous if the villous component comprised more than $75 \%$ of the surface. Only three adenomas had high grade dysplasia and therefore severity of dysplasia was not assessed any further in our study.

\section{DNA PREPARATION}

Genomic DNA was extracted separately from adenomatous tissue and control nonadenomatous colorectal tissue (polyp stalk or native colorectum in other specimens) by microdissection and prepared as described previously. ${ }^{35-37}$ DNA from adenomatous epithelium represented at least $50 \%$ tumour DNA. We were able to amplify DNA by polymerase chain reaction (PCR) from the majority of formalin fixed or Bouin's fixed tissue. DNA from peripheral blood was used when non-adenomatous tissue was not available.
POINT MUTATIONS OF K-ras PROTO-ONCOGENE The first exon of c-K-ras was amplified and all possible point mutations in the first and second nucleotide position in codon 12 and the second nucleotide position of codon 13, which account for the majority of K-ras mutations in colorectal neoplasms, were tested by three separate ligations of mutation allele specific oligonucleotides, as described previously. ${ }^{36} 37$ The ligation products were analysed on a $12 \%$ denaturing polyacrylamide gel. A band in the tumour lane corresponding to a band in the positive control lane indicated a mutation (fig 1). 

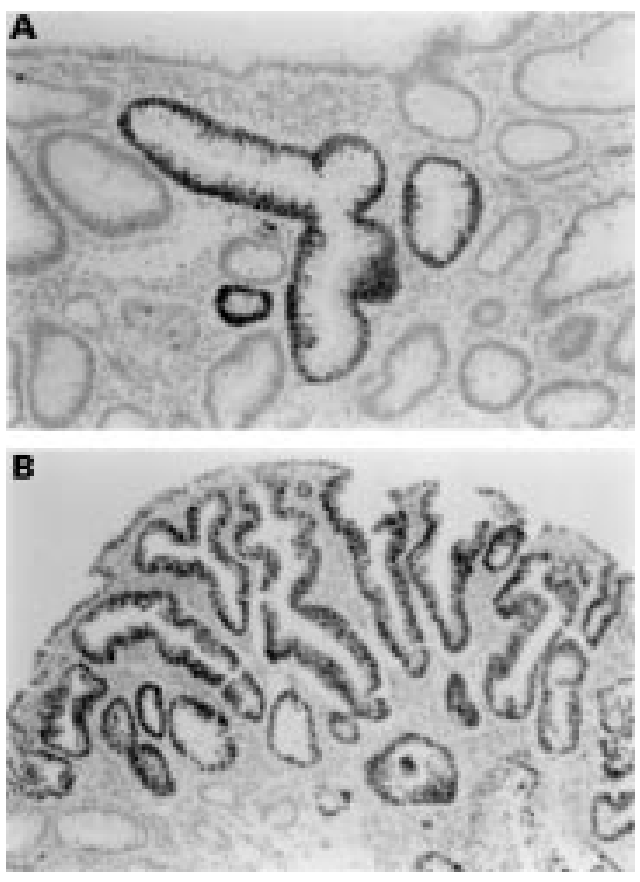

Figure 2 Immunohistochemistry for p53 gene products. (A) Focal staining of adenomatous epithelium. (B) Diffuse staining of an adenoma.

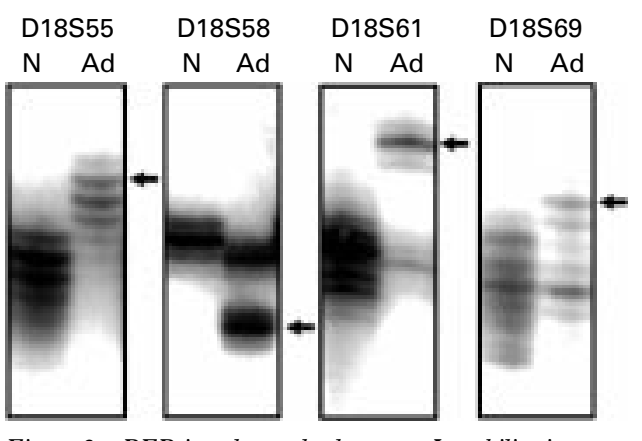

Figure 3 RER in colorectal adenomas. Instability in microsatellite markers is shown by additional bands (arrows). N, non-neoplastic; Ad, adenoma.

MICROSATELLITE MARKERS AND PCR AMPLIFICATION

Five dinucleotide repeat microsatellite markers on the long arm of chromosome 18 (D18S58, D18S61, D18S55, D18S64, and D18S69 in order from centromere to telomere) were used to determine loss of heterozygosity ( $\mathrm{LOH}$ ) of chromosome $18 \mathrm{q}$ and RER status. ${ }^{38}$ PCR based dinucleotide repeat assays were carried out in 96 well plates for 35 cycles; each cycle was carried out at $95^{\circ} \mathrm{C}$ for 30 seconds, $50^{\circ} \mathrm{C}$ for 30 seconds, and $70^{\circ} \mathrm{C}$ for one minute, in a buffer containing $83.75 \mathrm{mM}$ TRIS, pH 8.8, 20 $\mathrm{mM}(\mathrm{NH})_{2} \mathrm{SO}_{4}, 1.8 \mathrm{mM} \mathrm{MgCl}, 12.5 \mathrm{mM} \beta$ mercaptoethanol, $125 \mu \mathrm{g}$ bovine serum albu$\min$ (BSA), $250 \mu \mathrm{M}$ dATP, dGTP, and dTTP, $6.25 \mu \mathrm{M}$ dCTP, $0.05 \mu \mathrm{l}\left[\mathrm{a}^{32} \mathrm{P}\right] \mathrm{dCTP}$ (NEN DuPont; $3000 \mathrm{Ci} / \mathrm{mmol}$ ), $0.6 \mu \mathrm{M}$ PCR primers, and 0.5 units Taq DNA polymerase in 12 $\mu l$ volume. An equal volume of stop buffer (95\% formamide, $20 \mathrm{~mm}$ EDTA, and $0.05 \%$ bromophenol blue and xylene cynanol) was added at end of amplification, and the samples were loaded onto $8 \%$ polyacrylamide gels containing $5.6 \mathrm{M}$ urea. RER status or loss of heterozygosity of chromosome $18 \mathrm{q}$ could not be determined in 25 adenomas due to lack of non-adenomatous tissue or frozen blood sample $(n=8)$, or lack of PCR amplification in three or more markers $(n=17)$.

LOSS OF HETEROZYGOSITY OF CHROMOSOME 18q Loss of chromosome $18 \mathrm{q}$ is associated with loss of the DCC gene and its mRNA expression, ${ }^{17} 38$ the DPC4 gene, ${ }^{18}$ and the JV18 gene. ${ }^{19}$ Loss of a marker was considered to be present when the PCR assay showed absence or decrease in intensity by $50 \%$ of a band from a tumour sample compared with the control nonneoplastic sample. Complete or partial loss of each chromosome $18 \mathrm{q}$ was evaluated, based on the pattern of marker losses.

\section{IMMUNOHISTOCHEMISTRY FOR p53 GENE} PRODUCT

Immunohistochemistry with mouse monoclonal antibody D07 and standard techniques was used to determine p53 gene product overexpression, defined as staining of more than $50 \%$ of nuclei in adenomatous epithelium. This criterion was based on our previous studies showing this finding was strongly associated with p53 mutation in colorectal neoplasms. ${ }^{39}$ Topography of staining was defined as focal if five or fewer glands of adenomatous epithelium were intensely stained (fig $2 \mathrm{~A}$ ), regional if more than five crypts but less than $50 \%$ of adenomatous epithelium were stained, and diffuse if more than $50 \%$ of adenomatous epithelium was stained (fig 2B).

\section{RER STATUS}

The presence of DNA replication errors (RER) was determined from the PCR amplifications of the five dinucleotide microsatellite markers on the long arm of chromosome 18 (18q). RER positive adenomas were defined by shifts of bands as compared with control DNA in at least two microsatellite markers (fig 3). RER status could not be determined in 25 adenomas from 19 patients due to failure of DNA amplifications in three or more markers or lack of non-neoplastic tissue.

ALTERATIONS OF BAT-26 AND BAT-25 ALLELES Alterations of BAT-26, a polyadenine tract present in the intron 5 of $h M S H 2$ gene, and BAT-25, a polyadenine tract present in the intron of $c$-kit gene, were studied in RER positive adenomas as described previously. ${ }^{26}$ An unstable allele was defined by an additional band present below the wild type allelic band (fig 4).

\section{MUTATION IN TGFBRII GENE}

Alteration in the $10 \mathrm{bp}$ polyadenine tract present in the third exon of the TGF $\beta$ RII gene was studied by PCR amplification of a $73 \mathrm{bp}$ region, as described previously. ${ }^{26}$ Mutation was defined by an additional band present above or below the wild type allelic band (fig 5).

\section{STATISTICAL ANALYSIS}

The major statistical endpoint of this study was the determination of factors associated with genetic alterations in adenomas. Patients with 


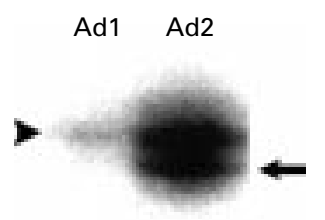

Figure 5 Adenoma (Ad 2) with one $b p$ deletion (arrow) in TGF $\beta$ type II receptor gene shown by PCR amplification of a 73 bp region. The normal length PCR product (Ad 1 and $A d 2)$ is indicated by an arrowhead. more than one adenoma were represented multiple times in this data set. To determine whether these repeated observations could be considered independent, $\chi^{2}$ goodness of fit tests were performed for each type of alteration. When the frequency of observed alterations was adequate, marginal logistic regression models for correlated binary data were used to assess associations with demographic features and adenoma characteristics. Estimates were obtained using the generalised estimating equation (GEE) approach of Liang and Zeger. ${ }^{40}$ When the within subject correlation is small, the independence working model for the GEE regression analysis has been shown to be adequate. For alterations where the assump-

Table 1 Patient demographics and adenoma characteristics

\begin{tabular}{|c|c|c|}
\hline & $\%$ of patients $(n=60)$ & $\%$ of polyps $(n=201)$ \\
\hline \multicolumn{3}{|l|}{ Race } \\
\hline African-American & $33(20)$ & $29(58)$ \\
\hline White & $65(39)$ & $70(140)$ \\
\hline Other & $2(1)$ & $1(3)$ \\
\hline \multicolumn{3}{|l|}{ Sex } \\
\hline Female & $42(25)$ & $36(73)$ \\
\hline Male & $58(35)$ & $64(128)$ \\
\hline \multicolumn{3}{|c|}{ Number of polyps analysed from each patient (range $1-17$, median 2) } \\
\hline 1 & $32(19)$ & $9(19)$ \\
\hline $2-5$ & $53(32)$ & $49(98)$ \\
\hline$>5$ & $15(9)$ & $42(84)$ \\
\hline \multicolumn{3}{|c|}{ Polyp size $(\text { mean } 0.7(\mathrm{SD} 0.7) \mathrm{cm})^{\star}$} \\
\hline $0.1-0.5$ & $75(45)$ & $63(126)$ \\
\hline$>0.5-1$ & $48(29)$ & $25(50)$ \\
\hline$>1-2$ & $27(16)$ & $9(18)$ \\
\hline$>2$ & $12(7)$ & $3(7)$ \\
\hline \multicolumn{3}{|l|}{ Histopathology } \\
\hline Tubular & $85(51)$ & $79(158)$ \\
\hline Tubulovillous & $48(29)$ & $20(41)$ \\
\hline Villous & $3(2)$ & $1(2)$ \\
\hline \multicolumn{3}{|l|}{ Site ${ }^{\star}$} \\
\hline Right colon & $57(34)$ & $51(102)$ \\
\hline Left colorectum & $83(50)$ & $47(95)$ \\
\hline Not designated & $7(4)$ & $2(4)$ \\
\hline
\end{tabular}

Age at polypectomy: range 28-91 years, mean 64 (11).

Colonoscopic examination per patient: range 1-5, median 2 .

*Total percentage for patients exceeds $100 \%$ due to multiple adenomas.

Table 2 Prevalence of genetic alterations in patients and adenoma

\begin{tabular}{|c|c|c|}
\hline Alteration & $\begin{array}{l}\text { Percentage of patients } * \\
\text { (fraction) }\end{array}$ & $\begin{array}{l}\text { Percentage of adenomas } \\
\text { (fraction) }\end{array}$ \\
\hline $\mathrm{K}$-ras mutation & $65(39 / 60)$ & $35 \quad(70 / 200) \dagger$ \\
\hline Positive p53 immunohistochemistry & $17(10 / 60)$ & $6(13 / 201)$ \\
\hline Loss of $18 \mathrm{q}$ & $8(4 / 53)$ & $2 \quad(4 / 176) \ddagger$ \\
\hline RER positivity & $15(8 / 53)$ & $7 \quad(13 / 176)$ \\
\hline HNPCC & $66(2 / 3)$ & $44 \quad(4 / 9) \S$ \\
\hline Non-HNPCC & $12(6 / 50)$ & $5 \quad(9 / 167)$ \\
\hline TGF $\beta$ RII mutation & $2(1 / 60)$ & $0.5(1 / 201)$ \\
\hline
\end{tabular}

${ }^{\star}$ Number of patients who have genetic alteration in an adenoma divided by total number of patients with a specimen analysed.

†K-ras mutation was not analysed in an adenoma due to non-amplification of DNA. $\neq \mathrm{p}=0.05$ versus $\mathrm{p} 53$ overexpression in adenomas.

$\mathrm{S}=0.002$ versus RER positive adenomas in non-HNPCC patients.

Table 3 Prevalence of genetic alterations compared with size, histopathology, and site of adenomas

\begin{tabular}{|c|c|c|c|c|}
\hline & $K$-ras mutation & p53 overexpression & Loss of $18 q$ & RER positive \\
\hline \multicolumn{5}{|l|}{ Size in $\mathrm{cm}$} \\
\hline $0.1-0.5$ & $31(39 / 125)$ & $6(8 / 126)$ & $3(3 / 110)$ & $5(5 / 110)$ \\
\hline$>0.5-1$ & $40(20 / 50)$ & $4(2 / 50)$ & $0(0 / 43)$ & $12(5 / 43)$ \\
\hline$>1$ & $44(11 / 25)$ & $12(3 / 25)$ & $4(1 / 23)$ & $13(3 / 23)$ \\
\hline \multicolumn{5}{|l|}{ Histopathology } \\
\hline Tubular & $33(52 / 158)$ & $3(5 / 158)$ & $3(4 / 139)$ & $6(8 / 139)$ \\
\hline Tubulovillous & $41(17 / 40)$ & $20(8 / 41)^{\star}$ & $0(0 / 35)$ & $14(5 / 35)$ \\
\hline Villous & $50(1 / 2)$ & $0(0 / 2)$ & $0(0 / 2)$ & $0(0 / 2)$ \\
\hline \multicolumn{5}{|l|}{ Site } \\
\hline Right & $34(35 / 102)$ & $3(3 / 102)$ & $1(1 / 89)$ & $9(8 / 89)$ \\
\hline Left & $35(33 / 94)$ & $11(10 / 95)$ & $4(3 / 84)$ & $6(5 / 84)$ \\
\hline
\end{tabular}

Results are expressed as \% (fraction).

${ }^{\star} \mathrm{p}=0.001$, villous and tubulovillous versus tubular adenomas.
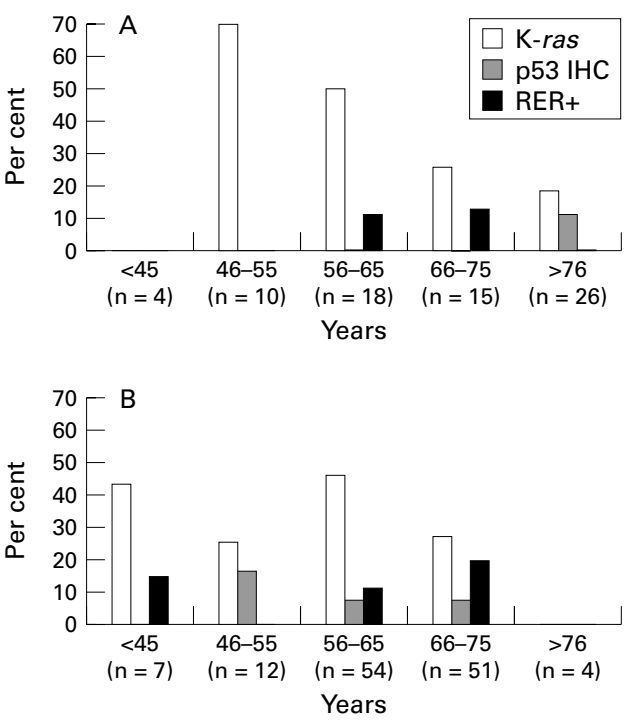

Figure 6 Genetic alterations in adenomas from female (A) and male (B) patients.

tion of independence was rejected due to one or two patients and the sample of observed alterations was too small for valid GEE regression, Fisher's exact tests were performed both with and without these patients. Factors tested for an association with K-ras included age, sex, site, adenoma size, villous component, $18 \mathrm{q}$ loss, p53 overexpression, and RER status. A formal statistical method for multiple comparisons was not performed because this was considered an exploratory study to generate hypotheses that can be tested in future studies.

\section{Results}

Table 1 summarises the demographics of the patient population and adenoma characteristics. Table 2 and fig 6 summarise the genetic alterations in colorectal adenomas. Table 3 compares the size, histopathology, and anatomical site of the adenomas.

CONCORDANCE OF GENETIC ALTERATIONS IN PATIENTS WITH MULTIPLE ADENOMAS

Forty one patients (68\%) had multiple adenomas which provided an opportunity for assessing within subject correlation of genetic alterations. In patients with multiple adenomas, K-ras mutation was present in $36 \%$ of adenomas (65/ 181), loss of heterozygosity of chromosome $18 \mathrm{q}$ in $2 \%(4 / 163)$, p53 overexpression in $6 \%$ (11/182), and RER in $7 \%$ (12/163). p53 overexpression was not independent in multiple adenomas ( $p=0.001, \chi^{2}$ goodness of fit) - that is, the occurrence of $\mathrm{p} 53$ overexpression in one adenoma significantly increased the probability of p53 overexpression in a second adenoma. This was primarily due to one patient with p53 overexpression in three of five adenomas. Within patient correlation for RER was also significant ( $p=0.001, \chi^{2}$ goodness of fit) due to two patients with RER alterations in both of two adenomas. By contrast, there was no statistically significant within subject correlation for K-ras mutation ( $p=0.55, \chi^{2}$ goodness of fit). Of the patients with two or more adenomas, $15 \%$ 
Table 4 K-ras point mutations in codons 12 and 13 in colorectal adenomas

\begin{tabular}{|c|c|c|c|}
\hline Codon 12 (amino acid) & $\begin{array}{l}\text { Codon } 13 \\
\text { (amino acid) }\end{array}$ & Type of mutation * & $\begin{array}{l}\text { Percentage of } \\
\text { adenomas (number) }\end{array}$ \\
\hline Wild type GGT (Gly) & $\begin{array}{l}\text { Wild type GGC } \\
\text { (Gly) }\end{array}$ & - & $65(131)$ \\
\hline \multicolumn{4}{|l|}{ Single mutation } \\
\hline GAT (Asp) & Wild type & $\mathrm{s} @ 12 \mathrm{~b}$ & $11(23)$ \\
\hline GTT (Val) & Wild type & V@12b & $9(18)$ \\
\hline GCT (Ala) & Wild type & V@12b & $1(2)$ \\
\hline TGT (Cys) & Wild type & $\mathrm{V} @ 12 \mathrm{a}$ & $4(9)$ \\
\hline Wild type & GAC (Asp) & $s @ 13 b$ & $1(2)$ \\
\hline Wild type & GTC (Val) & $\mathrm{V} @ 13 \mathrm{~b}$ & $0.5(1)$ \\
\hline \multicolumn{4}{|l|}{ Double mutations } \\
\hline GAT (Asp), GTT (Val) & Wild type & S@12b, V@12b & $2(5)$ \\
\hline TGT (Cys), GAT (Asp) & Wild type & V@12a, S@12b & $2(4)$ \\
\hline TGT (Cys), GTT (Val) & Wild type & V@12a,V@12b & $1(2)$ \\
\hline TGT (Cys), GCT (Ala) & Wild type & V@12a,v@12b & $0.5(1)$ \\
\hline GCT (Ala), GAT (Asp) & Wild type & $\mathrm{V} @ 12 \mathrm{~b}, \mathrm{~S} @ 12 \mathrm{~b}$ & $1(2)$ \\
\hline GCT (Ala), GTT (Val) & Wild type & V@12b, V@12b & $0.5(1)$ \\
\hline
\end{tabular}

*Transition denoted by S, transversion by V, followed by codon (12 or 13) and nucleotide 1 (a) or 2 (b).

Table 5 Odds ratios and 95\% confidence intervals (CI) for K-ras, from GEE marginal regression models

\begin{tabular}{llll}
\hline Factor & Odds ratio & $95 \%$ CI & $p$ Value \\
\hline $\begin{array}{l}\text { Age } \\
\quad<65 \mathrm{y}\end{array}$ & 1.00 & & \\
$\quad>65 \mathrm{y}$ & 0.44 & $(0.23,0.84)$ & 0.01 \\
$\begin{array}{l}\text { Sex } \\
\quad \text { Female }\end{array}$ & 1.00 & & \\
$\quad$ Male & 1.08 & $(0.53,2.18)$ & 0.84 \\
$\begin{array}{l}\text { Site } \\
\quad \text { Left }\end{array}$ & & & \\
$\quad$ Right & 1.00 & & \\
Villous component & 0.96 & $(0.53,1.72)$ & 0.89 \\
p53 & 1.00 & $(0.98,1.02)$ & 0.56 \\
$\quad$-ve & & & \\
$\quad$ +ve & 1.00 & & \\
RER & 1.18 & $(0.42,3.37)$ & 0.75 \\
$\quad$-ve & & & \\
$\quad+$ ve & 1.00 & & \\
Loss of 18q & 3.32 & $(1.08,10.19)$ & 0.04 \\
$\quad$-ve & & & \\
$\quad$ +ve & 1.00 & $(0.34,38.80)$ & 0.28 \\
Size & 3.64 & $(0.75,1.85)$ & 0.46 \\
\hline
\end{tabular}

(6/41) had K-ras mutations in all adenomas, $17 \%(7 / 41)$ had no K-ras mutation, and $68 \%$ (28/41) had K-ras mutations in one or more but not all of their adenomas.

C-K-ras MUTATIONS

Mutation in K-ras was the most frequent genetic alteration, occurring in 35\% of colorectal adenomas (70/200) representing $65 \%$ of the patients (table 2). The most frequently altered nucleotide position was the second nucleotide of codon 12, and the most common mutation was substitution of asparatic acid for glycine due to $\mathrm{G}$ to $\mathrm{A}$ transition ( $49 \%$ of K-ras mutations; table 4). Two ras mutations were found in $7 \%$ of adenomas (15/201), all involving codon 12 . In $53 \%$ of adenomas with two mutations, the same nucleotide position showed different mutations, indicating two subclones in the adenoma.

Patients 65 years of age and older had a significantly decreased probability of K-ras mutation in their adenomas (26\% versus $45 \%$, $\mathrm{p}=0.01$, GEE regression model; table 5), but there was no association of K-ras mutations with sex or site of adenoma. There was a slightly increased prevalence of K-ras mutations in villous or tubulovillous adenomas compared with tubular adenomas $(43 \%$ versus $33 \%, p=0.33$, GEE regression model; table 3 ), and in larger adenomas (31\% in adenomas 0.5 $\mathrm{cm}$ or less in size versus $41 \%$ in those more than $0.5 \mathrm{~cm}, \mathrm{p}=0.16$, GEE regression model; table 3 ), but the differences were not statistically significant.

LOSS OF HETEROZYGOSITY OF CHROMOSOME 18q Loss of heterozygosity of chromosome $18 \mathrm{q}$ was rare, present in only $2 \%$ of colorectal adenomas (4/176), and was significantly less frequent than p53 overexpression $(6 \%, 13 / 201$, $\mathrm{p}=0.05)$.

p53 OVEREXPRESSION

Overexpression of p53 gene product was present in $6 \%$ of colorectal adenomas (13/ 201). The staining was focal in seven adenomas and regional in four, suggesting the presence of subclones with p53 alteration, and diffuse in two. There was no difference in p53 overexpression in males and females (10/128 adenomas in males versus $3 / 73$ in females, $p=0.4)$. By contrast, in patients $50-75$ years of age, p53 overexpression was present exclusively in adenomas from male patients (10/128 adenomas in males versus $0 / 39$ adenomas in females, $\mathrm{p}=0.06$, Fisher's exact test; fig 5). p53 overexpression was seen in three adenomas from the left colorectum in two females over 75 years of age. There was increased frequency of p53 overexpression in tubulovillous adenomas compared with tubular adenomas (19\% versus $3 \%, p=0.001$, Fisher's exact test; table 3 ).

RER STATUS

RER was present in $7 \%$ of adenomas (13/176 tested) from eight patients. Of the 13 adenomas with RER phenotype evaluated by dinucleotide markers, one had mobility shifts in all five markers, one in four, two in three, and the remaining nine in two markers (at least $40 \%$ of dinucleotide markers). An unstable shortened allele of BAT- 26 was present in $36 \%$ of RER positive adenomas (4/11 adenomas with PCR amplification) from three patients. No unstable allele of BAT- 25 was detected in 11 RER positive adenomas.

Forty four per cent of adenomas from three HNPCC patients $(2 / 2,2 / 5$, and $0 / 2$, respectively) were RER positive versus $5 \%$ in non-HNPCC patients (table $2 ; \mathrm{p}=0.002$, Fisher's exact test). All four adenomas with RER phenotype from HNPCC patients had mobility shifts in two microsatellite markers and one had a shift in BAT-26. Another patient who had one of five adenomas with RER had a family history of hereditary colon cancer (see Materials and methods for definition). By contrast, four patients with RER in 3/12, 2/2, 1/11, 1/5, and $1 / 1$ adenomas had a negative family history. Seven of eight patients with RER positive adenomas had more than one adenoma (range 2-12). There was a correlation between RER in an adenoma and RER in a metachronous or synchronous adenoma ( $\mathrm{p}=0.001$, $\chi^{2}$ goodness of fit). Although RER positive cancers are commonly right sided, ${ }^{41}$ the RER positive adenomas were not significantly more common in right colon than left colorectum ( $9 \%$ versus $6 \%, p=0.56$, Fisher's exact test). Similarly, percentage of markers with shift was 
Table 6 Prevalence of multiple genetic alterations in colorectal adenomas

\begin{tabular}{lllll}
\hline Denominator & K-ras mutation & p53 overexpression & Loss of $18 q$ & RER positive \\
\hline K-ras mutation & - & $7(5 / 69)$ & $3(2 / 61)$ & $13(8 / 61)$ \\
p53 overexpression & $42(5 / 12)$ & - & $0(0 / 8)$ & $0(0 / 9)$ \\
Loss of 18q & $50(2 / 4)$ & $0(0 / 4)$ & - & $0(0 / 4)$ \\
RER positive & $62(8 / 13)$ & $0(0 / 13)$ & $0(0 / 13)$ & - \\
\hline
\end{tabular}

Results are expressed as \% (fraction).

not higher in right sided adenomas (45\% versus $50 \%, \mathrm{p}=0.81$ ). Among seven RER positive adenomas from HNPCC patients or adenomas with alteration of BAT-26 allele, four were right sided.

ALTERATION IN TGF $\beta$ RII

Mutation in the TGF $\beta$ RII gene was very rare, present in only one of 13 RER positive adenomas among 201 adenomas studied. This alteration was present in an RER positive tubulovillous adenoma from a patient without HNPCC.

MULTIPLE GENETIC ALTERATIONS IN ADENOMAS Adenomas with RER were more likely to have a K-ras mutation than adenomas without RER $(62 \%$ versus $33 \%, p=0.04$, GEE regression model; tables 5 and 6 ). K-ras mutation was present in $57 \%$ of RER positive adenomas from HNPCC patients or with alteration of BAT-26. Adenomas with K-ras mutation had more genetic alterations than adenomas without a K-ras mutation $(21 \%$ versus $11 \%$, $\mathrm{p}=0.09$, GEE regression model) including RER in eight adenomas, p53 overexpression in five, and loss of chromosome $18 \mathrm{q}$ in two. However, this marginally increased probability of K-ras mutation when any one of these alterations was present was due to the association of K-ras with RER positivity, and was not associated with $\mathrm{p} 53$ overexpression or chromosome $18 \mathrm{q}$ loss.

\section{Discussion}

The molecular genetics of colorectal neoplasms, including adenomas, have been studied extensively, but few studies have addressed clinical and pathological associations in prospectively defined patient populations. We therefore studied adenomas from patients without cancer in a cohort undergoing colonoscopy. The limitations of design in our study include multiple statistical comparisons and low frequency of genetic alterations in adenomas of patients without colorectal cancer. The significant associations generated in this study should be considered exploratory due to the low number of genetic events and should be addressed in future studies.

K-ras mutations were present in $35 \%$ of adenomas in our study. The reported prevalences of K-ras mutations in adenomas vary widely in the literature, from $20 \%$ to $70 \% .^{8-16}$ These variations in $\mathrm{K}$-ras mutation rates in colorectal adenomas may reflect geographical and dietary variations in exposure to putative carcinogenic agents in the study populations in different countries or use of different assay techniques in these studies. ${ }^{42}$ Clinical associations with $\mathrm{K}$-ras mutations in adenomas are also variable in the literature. K-ras mutations in adenomas are reported to be more common in patients with a prior colorectal cancer. ${ }^{10}{ }^{14}$ Lack of K-ras mutations in right sided colon carcinomas from patients younger than 70 years has been reported, ${ }^{43}$ but we found a lower prevalence of K-ras mutations in adenomas from older rather than younger patients. Our results corroborate a previous study which showed a low prevalence (18\%) of K-ras mutations in adenomas without a synchronous carcinoma in patients over 70 years of age. ${ }^{14}$ Correlations of K-ras mutation with size or histopathology show conflicting results in different studies, ${ }^{910}$ and we found no significant relation. A lower prevalence of K-ras mutations occurs in flat adenomas. ${ }^{11} 24$

Heterogeneity of K-ras mutations in microdissected areas within an adenoma and multiple K-ras mutations in individual colorectal adenomas have been reported, ${ }^{1644}$ and we found two mutations in $7 \%$ of our adenomas. Two mutations in an adenoma may represent either two individual subclones with two different mutations or mutations in both copies of K-ras. The type of mutations may be important as G-C or G-T transversions are present in colorectal adenomas with DNA aneuploidy, ${ }^{13}$ and transversions are more common in Dukes's C colorectal carcinomas in comparison to Dukes's B carcinomas ${ }^{45}$ and in recurrent colorectal carcinomas. ${ }^{46}$ By contrast, most of the mutations in our study were G-A transitions. Patients with a large adenoma (more than $1 \mathrm{~cm}$ ) harbouring a K-ras mutation are expected to have a significantly higher risk of developing a large metachronous adenoma, ${ }^{14}$ but our study showed no significance of K-ras mutation as a predictor of a K-ras mutation in synchronous or metachronous adenomas in patients with multiple adenomas. Nonconcordance of K-ras mutation in multiple adenomas in the same patient raises questions about the pathogenesis of K-ras alterations in colorectal neoplasms. In addition, our findings suggest that K-ras mutation in an adenoma is unlikely to be a reliable predictor of recurrence of adenomas in an individual patient.

Allelic loss of chromosome $18 \mathrm{q}$ is an event late in colorectal carcinogenesis as it is present in $70 \%$ of colorectal carcinomas, ${ }^{38}$ but is present in less than $20 \%$ of stage I carcinomas ${ }^{17}$ and $10 \%$ of adenomas. ${ }^{7}$ The loss of chromosome $18 \mathrm{q}$ is associated with loss of DCC, DPC4, and JV18 genes. ${ }^{17-19} 38$ Our results show that loss of chromosome 18 is present in only $2 \%$ of sporadic adenomas in a colonoscopic series. This low rate could reflect the small size of polyps in this study ( $97 \%$ of polyps were 2 $\mathrm{cm}$ or less in size).

p53 overexpression of the type associated with p53 gene mutation was present in $6 \%$ of adenomas, representing a higher frequency than $18 \mathrm{q}$ loss in our study. The distribution of overexpression is of interest because the abnormality was usually present regionally in neoplastic epithelium, suggesting that a subclone with p53 overexpression emerged late in tumourigenesis. Similar results have been reported in the literature, with alterations in 
p53 present in 5-26\% of colorectal adenomas, ${ }^{8920-23}$ in $53 \%$ of carcinomatous foci in adenomas, ${ }^{22}{ }^{23}$ and in $70 \%$ of carcinomas. ${ }^{20}{ }^{21}$

We observed RER in 7\% of adenomas representing eight patients, based on the criterion of at least two of five dinucleotide markers with allelic shift. Five of the patients had two or more adenomas with RER by our criterion, and two of these patients were members of HNPCC kindreds. RER has been observed in up to $3 \%$ of sporadic adenomas ${ }^{29-32}$ and $60-95 \%$ of adenomas from HNPCC families. ${ }^{27}{ }^{29-31}$ Alteration in BAT-26 alleles was present in $36 \%$ of RER positive adenomas in our study, which is similar to the frequency of $50 \%$ in RER positive adenomas reported in the literature. ${ }^{47}$ Frameshift mutation in TGF $\beta$ RII has been observed in $57 \%$ of adenomas from HNPCC families, ${ }^{27}$ but infrequently in sporadic adenomas, ${ }^{33}$ and is present late in the adenoma-carcinoma sequence. ${ }^{47}$ We found mutation in the TGF $\beta$ RII gene in only one RER positive adenoma ( $8 \%$ ) and in none of the RER negative adenomas. ${ }^{27}$ We therefore confirmed previous studies indicating that alteration of mononucleotide markers (BAT-26, TGF $\beta$ RII, etc.), which is a sensitive predictor of high microsatellite instability in colorectal adenocarcinomas, is not frequent in adenomas. $^{33} 47$ Thus, the distinction between "low" microsatellite instability and "high" microsatellite instability ${ }^{48}$ is problematical in adenomas.

The occurrence of K-ras mutations in 50\% of RER positive adenomas from HNPCC patients has been reported, ${ }^{27}$ and we found that RER positive adenomas had increased probability of K-ras mutation. The frequency of $\mathrm{K}$-ras mutations in RER positive colorectal tumours is not settled because the mutations are reported to occur at frequencies similar to microsatellite stable cancers in some series, ${ }^{50-54}$ but at low frequency in others. ${ }^{31}$ It is speculated that K-ras may not have a major role in progression of RER positive colorectal tumours. $^{55}$

We found a high proportion of RER positive adenomas in the left colorectal tumours as well as a high frequency of K-ras mutation in RER positive adenomas. By contrast, RER positive colorectal cancers are strongly right sided. ${ }^{41}$ Thus, a right sided predilection or a lower frequency of K-ras mutation was not observed even in RER positive adenomas from HNPCC kindreds or adenomas with alteration of BAT-26. The differences between the features of RER positive adenomas and cancers remain to be explained.

In conclusion, our study shows the complexity of the genetic alterations involved in colorectal tumourigenesis. Factors related to patient age and RER are involved in the occurrence of K-ras mutations, as evidenced by the lower frequency of ras mutations in older patients and the higher frequency in RER positive adenomas which are associated with HNPCC in some patients. By contrast, p53 alterations have less intraindividual variation, favouring different aetiological factors than those for K-ras mutations.
We acknowledge Ms Rahj Robinson for recruitment of patients for this study, Mrs Nancy Folker for typing the manuscript, and Ms Ellen Winslow for photographs. This study was supported in part by the Clayton Fund and grants CA63718, CA62924, and CA41108 from the National Cancer Institute, National Institute of Health. The contents of this publication are solely the responsibility of the authors and do not necessarily represent the official views of the National Cancer Institute.

1 Kinzler KW, Vogelstein B. Lessons from hereditary colorectal cancer. Cell 1996;87:159-70.

2 Reale MA, Fearon ER. Gene defects in colorectal Reale MA, Fearon ER. Gene defects in colorectal
tumorigenesis. In: Young GP, Rozen P, Levin B, eds. tumorigenesis. In: Young GP, Rozen P, Levin B, eds.
Prevention and early detection of colorectal cancer. London: Prevention and early detection

3 Marra G, Boland CR. Hereditary nonpolyposis colorectal cancer (HNPCC): the syndrome, the genes, and historical perspectives. F Natl Cancer Inst 1995;87:1114-25.

4 Perucho M. Microsatellite instability: the mutator that mutates the other mutator. Nat Med 1996;2:630-1.

5 Miyaki M, Seki M, Okamoto M, et al. Genetic changes and histopathological types in colorectal tumors from patients with familial adenomatous polyposis. Cancer Res 1990;50: 7166-73.

6 Powell SM, Zilz N, Beazer-Barclay Y, et al. APC mutations occur early during colorectal tumorigenesis. Nature 1992; 359:235-7.

7 Boland CR, Sato J, Appelman HD, et al. Microallelotyping defines the sequence and tempo of allelic losses at tumor suppressor gene loci during colorectal cancer progression. Nat Med 1995;1:902-9.

8 De Benedetti L, Varesco L, Pellegata NS, et al. Genetic events in sporadic colorectal adenomas: K-ras and p53 heterozygous mutations are not sufficient for malignant progression. Anticancer Res 1993;13:667-70.

9 Scott N, Bell SM, Sagar P, et al. p53 expression and K-ras mutation in colorectal adenomas. Gut 1993;34:621-4

10 McLellan EA, Owen RA, Stepniewska KA, et al. High frequency of K-ras mutations in sporadic colorectal adenomas. Gut 1993;34:392-6.

11 Yamagata S, Muto T, Uchida Y, et al. Lower incidence of K-ras codon 12 mutation in flat colorectal adenomas than in polypoid adenomas. Fpn f Cancer Res 1994;85:147-51. Ajiki T, Fujimori T, lkehara $\mathrm{H}$, et al. K-ras gene mutation mas. Biotech Histochem 1995;70:90-4.

13 Giaretti W, Pujic N, Rapallo A, et al. K-ras-2 G-C and G-T transversions correlate with DNA aneuploidy in colorectal transversions correlate with DNA aneuploidy

14 Morris RG, Curtis LJ, Romanowski P, et al. Ki-ras mutations in adenomas: a characteristic of cancer-bearing mutations in adenomas: a characteristic of cance

15 Nusko G, Sachse R, Mansmann U, et al. K-ras-2 gene mutations as predictors of metachronous colorectal adenomas. Scand $\mathcal{F}$ Gastroenterol 1997;32:1035-41.

16 Saraga E, Bautista D, Dorta G, et al. Genetic heterogeneity in sporadic colorectal adenomas. F Pathol 1997;181:281-6.

17 Kikuchi-Yanoshita R, Konishi M, Fakunari H, et al. Loss of expression of the DCC gene during progression of colorectal carcinomas in familial adenomatous polyposis and nonfamilial adenomatous polyposis patients. Cancer Res 1992; 52:3801-3.

18 Thiagalingam S, Lengauer C, Leach FS, et al. Evaluation of candidate tumor suppressor genes on chromosomes 18 in colorectal cancers. Nat Genet 1996;13:343-6.

19 Riggins GJ, Thiagalingam S, Rozenblum E, et al. MadRiggins GJ, Thiagalingam S, Rozenblum E, et al. Mad
related genes in the human. Nat Genet 1996;13:347-9.

20 Darmon E, Cleary KR, Wargovich MJ. Immunohistochemical analysis of p53 overexpression in human colonic tumors. Cancer Detection Prevention 1994;18:187-95.

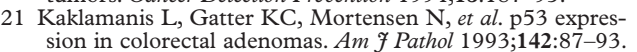
22 Ohue M, Tomita N, Monden T, et al. A frequent alteration of p 53 gene in carcinoma in adenoma of colon. Cancer Res 1994;54:4798-804.

23 Yamaguchi A, Makimoto K, Goi T, et al. Overexpression of p53 protein and proliferative activity in colorectal adenoma. Oncology 1994;51:224-7.

24 Hasegawa $\mathrm{H}$, Ueda $\mathrm{M}$, Watanabe $\mathrm{M}$, et al. K-ras gene mutations in early colorectal cancer. Flat elevated vs polypforming cancer. Oncogene 1995;10:1413-16.

25 Yamagata S, Muto T, Uchida Y, et al. Polypoid growth and K-ras codon 12 mutation in colorectal cancer. Cancer K-ras codon 12

26 Parsons R, Myeroff LL, Liu B, et al. Microsatellite instability and mutations of the transforming growth factor $\beta$ type II receptor gene in colorectal cancer. Cancer Res 1995;55: $5548-50$.

27 Akiyama Y, Iwanaga R, Saitoh K, et al. Transforming growth factor $\beta$ type II receptor gene mutations in adenomas from hereditary nonpolyposis colorectal cancer. Gastroenterology 1997;112:33-9.

28 Young J, Leggett B, Gustafson C, et al. Genomic instability occurs in colorectal carcinomas but not in adenomas. Hum Mutat 1993;2:351-4.

29 Aaltonen LA, Peltomaki P, Mecklin J-P, et al. Replication errors in benign and malignant tumors from hereditary nonpolyposis colorectal cancer patients. Cancer Res 1994; 54:1645-8.

30 Jacoby RF, Marshall DJ, Kailas S, et al. Genetic instability associated with adenoma to carcinoma progression in hereditary nonpolyposis colon cancer. Gastroenterology
1995;109:73-82. 
31 Konishi M, Kikuchi-Yanoshita R, Tanaka K, et al. Molecular nature of colon tumors in hereditary nonpolyposis colon
cancer, familial polyposis, and sporadic colon cancer. Gascancer, familial polyposis, and

32 Samowitz WS, Slattery ML. Microsatellite instability in colorectal adenomas. Gastroenterology 1997;112:1515-19.

33 Samowitz WS, Slattery ML. Transforming growth factor- $\beta$ receptor type 2 mutations and microsatellite instability in sporadic colorectal adenomas and carcinomas. Gastroenterology 1997;151:33-5.

34 Vasen HLA, Mecklin J-P, Merra Khan P, et al. The international collaborative group on hereditary nonpolyposis colorectal cancer (ICG-HNPCC). Dis Colon Rectum 1991;34:424-5.

35 Goelz SE, Hamilton SR, Vogelstein B. Purification of DNA from formaldehyde fixed and parraffin embedded human tissue. Biochem Biophys Res Commun 1985;130:118-26.

36 Jen J, Powell SM, Papadopoulos N, et al. Molecular determinants of dysplasia in colorectal lesions. Cancer Res determinants of

37 Rashid A, Hamilton SR. Genetic alterations in sporadic and Crohn's-associated adenocarcinomas of the small intestine. Crohn's-associated adenocarcinom

38 Jen J, Kim H, Piantadosi S, et al. Allelic loss of chromosome $18 \mathrm{q}$ and prognosis in colorectal cancer. New Engl f Med 1994;331:213-21.

39 Baas IO, Mulder J-WR, Offerhaus GJA, et al. An evaluation of six antibodies for immunohistochemistry of mutant p5 gene product in archival colorectal neoplasms. 7 Pathol 1994; 172:5-12.

40 Liang K-Y, Zeger SL. Longitudinal data analysis using generalized linear models. Biometrika 1986;73:13-22.

$41 \mathrm{Kim} \mathrm{H}$, Jen, J, Vogelstein B, et al. Clinical and pathological characteristics of sporadic colorectal carcinomas with DNA replication errors in microsatellite sequences. Am f Pathol 1994;145:148-56.

42 Hayashi N, Sugai S, Ito I, et al. Ethnic difference in the pattern of K-ras oncogene mutations in human colorectal can-

43 Breivik J, Meling GI, Spurkland A, et al. K-ras mutation in colorectal cancer: relations to patient age, sex and tumor location. Br f Cancer 1994;69:367-71.
44 Shibata D, Schaeffer J, Li Z-H, et al. Genetic heterogeneity of the c-K-ras locus in colorectal adenomas but not in adenocarcinomas. 7 Natl Cancer Institute 1993;85:1058-63.

45 Moerkerk P, Arends JW, van Driel M, et al. Type and number of Ki-ras point mutations relate to stage of human colorectal cancer. Cancer Res 1994;54:3376-8.

46 Benhattar J, Losi L, Chaubert P, et al. Prognostic significance of K-ras mutations in colorectal carcinoma. Gastroenterology 1993;104:1044-8.

47 Grady WM, Rajput A, Myeroff L, et al. Mutation of the type II transforming growth factor $\beta$ receptor is coincident with the transformation of human colon adenomas to malignant carcinomas. Cancer Res 1998;58:3101-4.

48 Dietmaier W, Wallinger S, Bocker T, et al. Diagnostic microsatellite instability: definition and correlation with mismatch repair protein expression. Cancer Res 1997:57:474956.

49 Boland CR, Thibodeau SN, Hamilton SR, et al. A National Cancer Institute workshop on microsatellite instability for cancer detection and familial predisposition: development of international criteria for the determination of microsatellite instability in colorectal cancer. Cancer Res 1998;58: 5248-57.

50 Aaltonen LA, Peltomaki P, Leach FS, et al. Clues to the pathogenesis of familial colorectal cancer. Science 1993: 260:812-16.

51 Craanen ME, Blok P, Offerhaus GJ, et al. Recent developments in hereditary non-polyposis colorectal cancer. Scand $\mathcal{F}$ Gastroenterol Suppl 1996:218:92-7.

52 Ruschoff J, Dietmaier W, Luttges J, et al. Poorly differentiated colonic adenocarcinomas, medullary type: clinical, phenotypic, and molecular characteristics. Am 7 Pathol 1997;150:1815-25.

53 Tannergard P, Liu T, Weger A, et al. Tumorigenesis in colorectal tumors from patients with hereditary non-polyposis colorectal cancer. Hum Genet 1997;101:51-5.

54 Olschwang S, Hamelin R, Laurent-Puig P, et al. Alternative genetic pathways in colorectal carcinogenesis. Proc Natl genetic pathways in colorectal
Acad Sci USA 1997;94:12122-7.

55 Arends JW, Bosman FT. The conceptual and practical impact of Ki-ras mutation in colorectal neoplasia. $\mathcal{F}$ Pathol 1996;180:355-6. 